\title{
Movement of carbon among estuarine habitats: the influence of saltmarsh patch size
}

\author{
Michaela A. Guest ${ }^{1,2,3, *}$, Rod M. Connolly ${ }^{1,2}$ \\ ${ }^{1}$ Centre for Aquatic Processes \& Pollution, and School of Environmental \& Applied Sciences, Gold Coast Campus, \\ Griffith University, PMB 50, Gold Coast Mail Centre, Queensland 9726, Australia \\ ${ }^{2}$ Cooperative Research Centre for Coastal Zone, Estuary and Waterway Management, Queensland 4068, Australia \\ ${ }^{3}$ Present address: Tasmanian Aquaculture and Fisheries Institute, University of Tasmania, GPO Box 252-49, Hobart 7001, \\ Tasmania, Australia
}

\begin{abstract}
We used carbon stable isotopes to examine the influence of the size of saltmarsh patches on the trophic contribution of saltmarsh grass and mangroves to 2 species of resident crabs (Parasesarma erythrodactyla and Australoplax tridentata). Crabs were collected at different distances across the saltmarsh-mangrove interface at each of 10 saltmarshes of different sizes (0.01 to 8.10 ha) adjacent to mangrove forests (each $>4$ ha). The $\delta^{13} \mathrm{C}$ values of crabs at all 10 marshes fitted a sigmoidal curve, with rapidly changing $\delta^{13} \mathrm{C}$ values across the saltmarsh-mangrove interface (the transition zone). The size of saltmarsh patches had a significant effect on $\delta^{13} \mathrm{C}$ values of $P$. erythrodactyla collected in the saltmarsh, with a similar trend shown by A. tridentata. On large saltmarshes $(>0.4 \mathrm{ha}), \delta^{13} \mathrm{C}$ values of crabs $(P$. erythrodactyla, $-15.9 \%$; A. tridentata, -15.4 ) collected $>5 \mathrm{~m}$ onto the saltmarsh matched that of the saltmarsh grass Sporobolus virginicus (-15.5). Carbon movement and assimilation by crabs was limited to $<5 \mathrm{~m}$. On small saltmarshes $(<0.3 \mathrm{ha}), \delta^{13} \mathrm{C}$ values of saltmarsh crabs ( -18.1 and -16.8 , respectively) were depleted, indicating assimilation of carbon from $S$. virginicus, but also from a more depleted allochthonous source, e.g. mangroves (-28.1), microphytobenthos (-23.7), or phytoplankton (ca. -20). Saltmarsh patch size did not affect the extent of carbon movement or assimilation by crabs in mangroves. Given that habitat patch size can influence pathways of carbon supply to invertebrates, the role of estuarine habitats in food webs cannot be assumed to be independent of the size and configuration of habitats.
\end{abstract}

KEY WORDS: Landscape ecology $\cdot$ Trophic ecology $\cdot$ Stable isotopes $\cdot$ Avicennia marina $\cdot$ Crustacea

\section{INTRODUCTION}

The influence of landscape structure on the abundance and distribution of organisms is a basic tenet of landscape ecology (Forman \& Godron 1986). Landscape structure, or what has more recently been termed landscape mosaics (e.g. Arguiar \& Sala 1999), refers to the distribution, orientation, age, size, shape and number of habitat patches, where 'patches' are commonly defined as an area that is visually distinct from its surroundings (Forman \& Godron 1986). Much of the effort examining the biological consequences of landscape structure has focused on terrestrial land- scapes (e.g. Robinson et al. 1992), but ecoscapes in the sea (Kneib 2000) are the subject of increasing attention (e.g. Hemminga et al. 1998, Frost et al. 1999).

In both terrestrial and marine settings, counts of animal and plant diversity and abundance are common means by which the response of organisms to characteristics of landscape structure is assessed (Cadenasso et al. 2004). For example, a review of 20 terrestrial studies of habitat fragmentation found that most focused on the effects of habitat size on species richness or on abundances of individual species (Debinski \& Holt 2000). Other aspects of terrestrial landscape structure commonly explored using measures of diver- 
sity and abundance of organisms are comparisons between 'edge' and 'core' habitat (Fox et al. 1997), as well as the age of habitat patches (Brooks et al. 1999). In marine settings, patch size has also been the most commonly explored aspect (Bell et al. 2001), often with reference to the influence of edge and core habitat. In contrast to the structure of populations and assemblages of animals, the relationship between ecological processes and landscape structure has received much less attention, particularly in marine systems (however, for predator-prey interactions across habitat boundaries, see e.g. Donovan et al. 1997, Cantrell et al. 2001).

Food webs are an aspect of ecological processes central to our understanding of how natural systems are organised (Polis et al. 1997). One focus of food web processes in marine and estuarine settings has been the movement of carbon from intertidal habitats to offshore environments (e.g. Kneib 2000, Bouillon et al. 2004), thus creating the first link between large-scale landscape structure and trophic contribution. Few marine or estuarine studies, however, have examined the relationships between food web processes and detailed characteristics of landscape structure such as patch size (but see Gremillet et al. 2004). Understanding the trophic function of small patches of habitat provides empirical evidence with which to evaluate the relative conservation value of habitats for inclusion into Marine Protected Areas at a scale more consistent with the scale of management in estuarine systems (Stevens \& Connolly 2004).

We used stable isotopes of carbon and naturally fragmented saltmarsh habitat adjacent to mangrove forests to examine the influence of habitat size on the movement of carbon and its assimilation by resident invertebrates. These saltmarsh and mangrove habitats are suited to isotope analysis because the $\delta^{13} \mathrm{C}$ values of the dominant autotrophs are clearly separated (Guest et al. 2004a). As water is the principal vector for the transport of carbon across habitat boundaries in aquatic systems (Polis et al. 1997), animals within these habitats, even sedentary ones, may derive their carbon from sources outside the habitat they occupy. Sedentary animals are therefore useful test organisms, because their home range is limited and carbon sources can be more clearly differentiated into those produced locally and those produced further away. Results from the same estuary as that used in the current study (Guest \& Connolly 2004, Guest et al. 2004a) showed that the movement of carbon and its assimilation by resident invertebrates in adjacent saltmarsh and mangrove habitats is limited to $<10 \mathrm{~m}$ where the sizes of saltmarshes were all about 2 ha. The current survey measured the influence of habitat size on the small-scale movement of carbon and its assimilation by 2 resident, detritivorous crab species.
Movement of carbon among estuarine habitats occurs at least partly as particulate matter, and we based our hypotheses on the concept that larger patches would generate more particulate matter and that some of this would be available for dispersal to adjacent habitats. We predict, therefore, that, for large saltmarsh patches, saltmarsh carbon will move further into adjacent mangrove habitat and be assimilated by the mangrove crabs (Fig. 1). This means that in mangroves adjacent to large saltmarsh patches, the $\delta^{13} \mathrm{C}$ values of mangrove crabs will reflect the assimilation of some saltmarsh carbon. Crabs in mangroves adjacent to small patches of saltmarsh, where the total pool of particulate saltmarsh material is predicted to be small, should show little assimilation of saltmarsh carbon. In this scenario, mangrove crab $\delta^{13} \mathrm{C}$ values will be similar to the dominant autotroph in the mangroves (i.e. mangroves or microphytobenthos). In large saltmarsh patches, the $\delta^{13} \mathrm{C}$ values of crabs resident in saltmarsh are predicted to be similar to that of the dominant autotroph in the saltmarsh (i.e. saltmarsh grass). For small saltmarsh patches, mangrove carbon will move into the adjacent saltmarsh and be assimilated by the crabs. We predict that in these small saltmarsh patches, the $\delta^{13} \mathrm{C}$ values of the saltmarsh crabs will be more similar to the dominant autotrophs of the adjacent mangroves than to the saltmarsh in which they reside.

\section{MATERIALS AND METHODS}

Saltmarsh and mangrove habitats were sampled in April 2003 in southern Moreton Bay, Queensland, Australia (Fig. 2). Ten sites of adjacent saltmarsh and mangrove habitat were chosen where saltmarsh habitat was dominated by the saltmarsh grass Sporobolus virginicus and the mangroves by Avicennia marina. These species were chosen over other estuarine species in southern Moreton Bay because of the clear separation of their carbon isotope values (Guest et al. 2004a), their proximity to each other and their abundance throughout the study region. Patches of saltmarsh were defined visually by an abrupt change in vegetation type on 3 sides, with the fourth bounded at the upper intertidal edge by estuarine water. Saltmarsh patches were between 0.01 and 8.10 ha in area (see Fig. 3), and adjacent mangrove forests were at least $4 \mathrm{ha}$. We selected saltmarsh patches approximately rectangular in shape, with the longer edge of the rectangle abutting the mangroves, to standardise the potential influence of patch orientation and perimeter to area ratio across patches. The saltmarshes had low relief $(<0.5 \mathrm{~m}$ change in elevation) and were inundated on at least 1 high tide per day for 2 wk out of the 4 wk sampling period, with a tidal range of about $1.3 \mathrm{~m}$. 


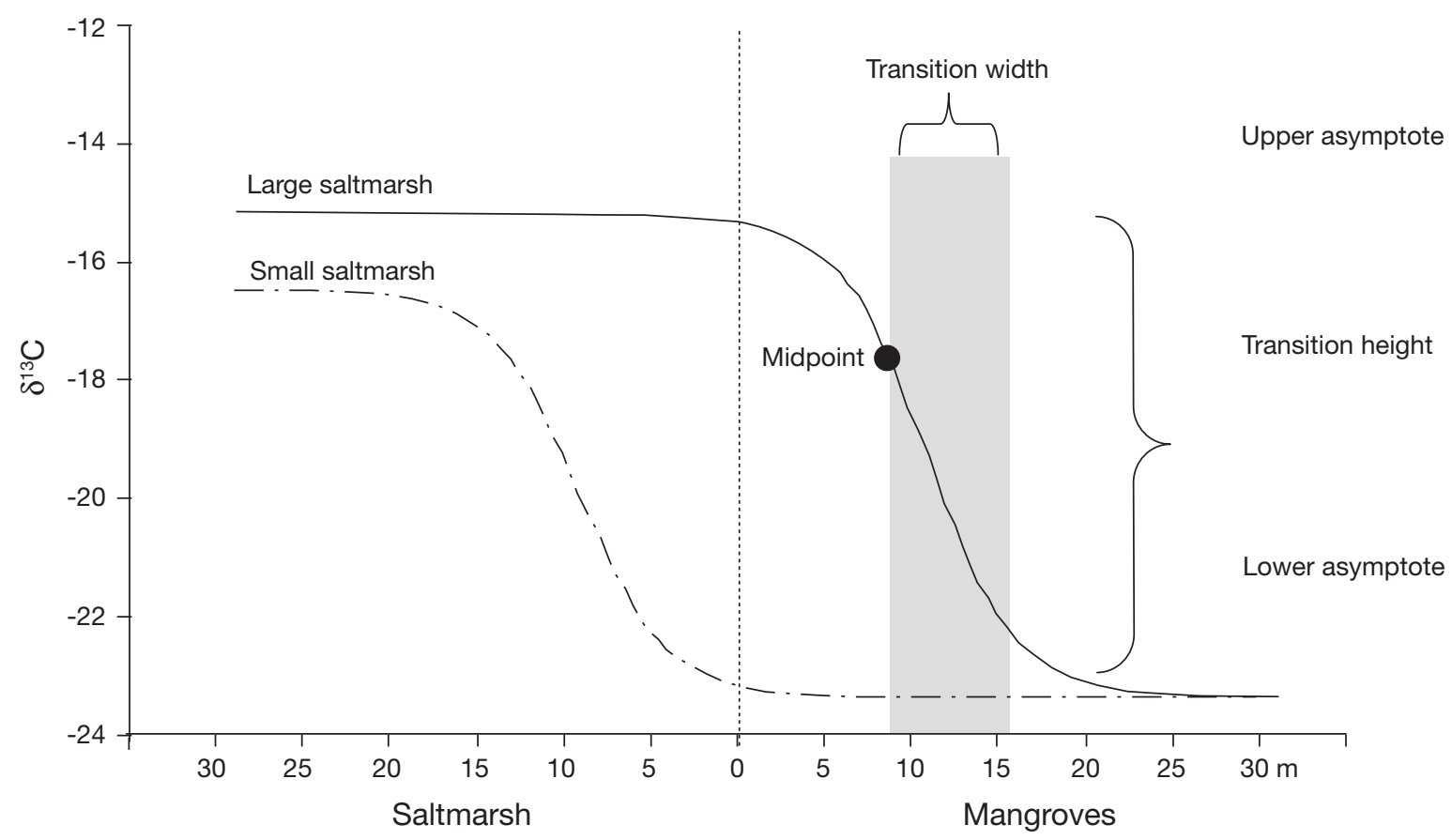

Fig. 1. Predicted non-linear patterns of invertebrate isotope values at different distances from the saltmarsh-mangrove interface in large and small marshes. The parameters expected to best describe these patterns are labelled (upper asymptote, the $\delta^{13} \mathrm{C}$ value of crabs in saltmarsh; lower asymptote, the $\delta^{13} \mathrm{C}$ value of crabs in mangroves; transition height, the difference in $\delta^{13} \mathrm{C}$ values between the upper and lower asymptote; midpoint, the centre of the transition zone along the $x$-axis; transition width, the distance carbon moves into the adjacent habitat from the midpoint)

Two crab species, Australoplax tridentata (Ocypodidae) and Parasesarma erythrodactyla (Grapsidae), were chosen for analysis, because they are found in both saltmarsh and mangroves and because they rarely move $>1 \mathrm{~m}$ from their burrows (Guest 2004). Their carbon isotope values therefore provide a good

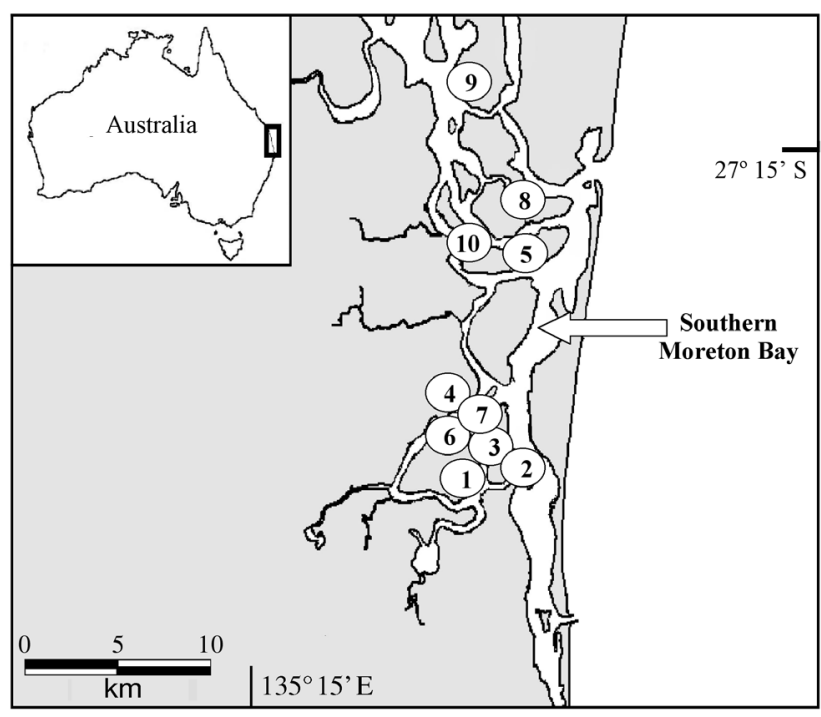

Fig. 2. Study area in southern Moreton Bay, with adjacent saltmarsh and mangrove sites numbered in order of size test of the movement and assimilation of carbon among adjacent habitats.

At each of the 10 locations, samples of both crab species were collected at the saltmarsh-mangrove interface (or zero point), and at 2, 4, 8, 16 and $30 \mathrm{~m}$ positions from the zero point into both saltmarsh and mangroves. However, some saltmarsh patches were too small to permit collections $30 \mathrm{~m}$ into the saltmarsh, and, in the smallest patch, crabs could only be collected up to $8 \mathrm{~m}$ into the saltmarsh. Crabs of a similar size (mean $13.7 \pm 0.1 \mathrm{~mm}$ carapace width for Parasesarma erythrodactyla and $10.6 \pm 0.1 \mathrm{~mm}$ for Australoplax tridentata) were collected at each position to minimise the possibility of intraspecific variability in isotope ratios of carbon due to ontogenetic shifts in diet (France 1998). The flesh from 2 to 3 crabs was pooled to provide enough tissue for analysis for each sample in each patch.

Three samples of Sporobolus virginicus and Avicennia marina were collected $30 \mathrm{~m}$ from the saltmarshmangrove interface at each site (i.e. 3 samples per site). Carbon isotope values of both $S$. virginicus (Guest et al. 2004b) and A. marina (Connolly et al. 2003) from different positions within a patch have previously been shown to be within $1 \%$. Carbon isotope values of microphytobenthos (MPB) collected at 30, 10 and $2 \mathrm{~m}$ positions in saltmarsh and mangrove habitats 

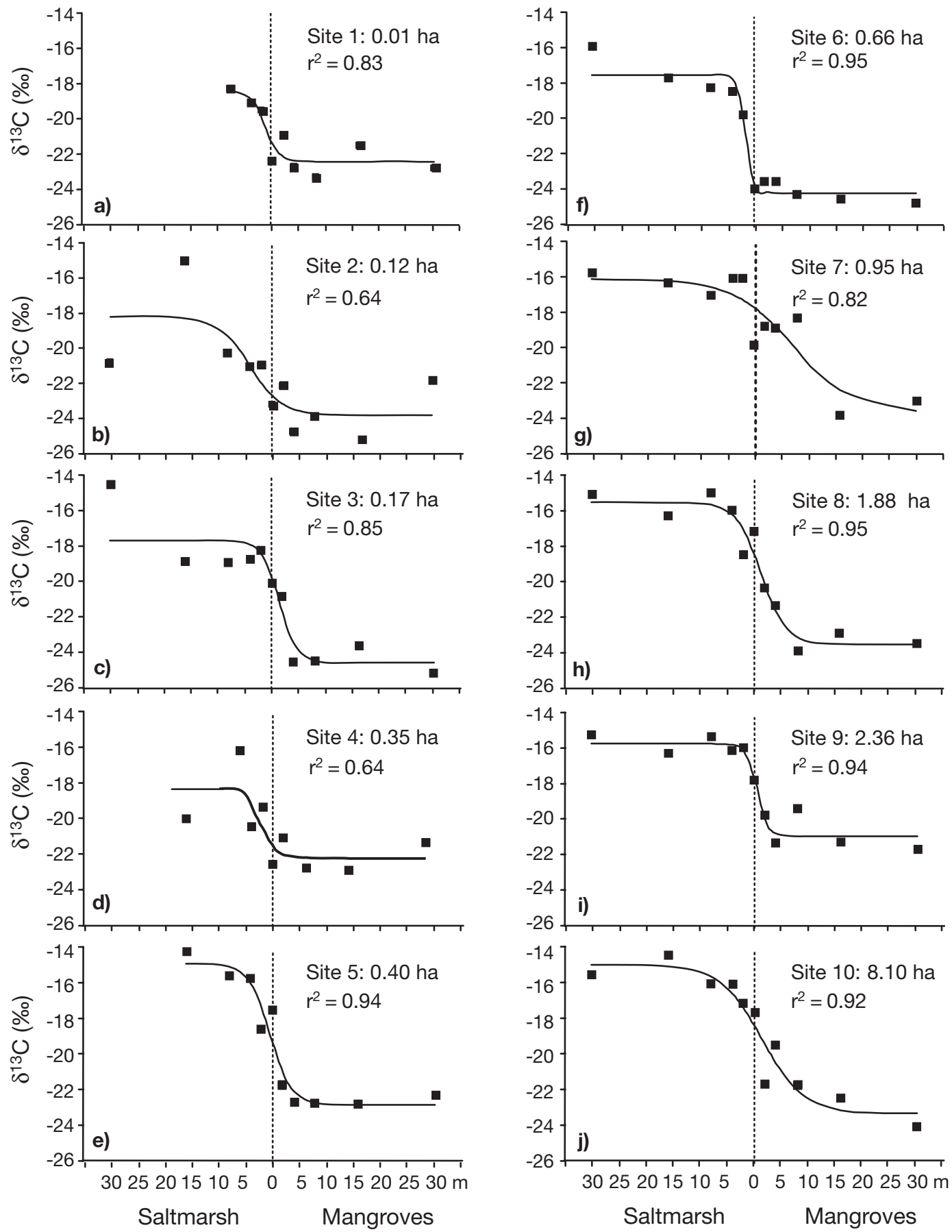

Fig. 3. Parasesarma erythrodactyla. Non-linear regression line of best fit for $\delta^{13} \mathrm{C}$ values and sampling positions for each site. Sites are numbered 1 to 10 in increasing order of saltmarsh patch size

at 3 of the 10 sites had previously been reported (Guest \& Connolly 2004), and these values were used again here. MPB samples consisted predominantly of diatoms isolated by centrifuging superficial sediment in silica gel (Guest et al. 2004a).
All samples were dried and ground (for crabs, the exoskeleton, shell and gut were removed), and their isotopic values were analysed on an Isoprime mass spectrometer. The ratios of ${ }^{13} \mathrm{C} /{ }^{12} \mathrm{C}$ were calculated as the relative difference (\%) between the sample and the 
recognised standard (Pee Dee belemnite limestone carbonate). Precision of the mass spectrometer, calculated using values from duplicate samples, was $0.2 \%$.

At each location, the relationship between $\delta^{13} \mathrm{C}$ values of each crab species and sampling positions across saltmarsh and mangrove habitats was clearly curvilinear. We therefore used non-linear regression in SPSS (Release 11.5.0, 2002, standard version for Windows) to determine the best fitting sigmoidal curve, of the form:

$$
y=\frac{a}{1+\exp \left(-\frac{x-b}{c}\right)}+d
$$

where $a$ is the transition height, i.e. the difference in $\delta^{13} \mathrm{C}$ between upper (saltmarsh) and lower (mangrove) asymptotes; $b$ is the transition midpoint, i.e. the centre of the transition zone along the $x$-axis; and $d$ is the value of $y$ when $x$ approaches its smallest value, i.e. the lower asymptote (Fig. 1). The transition width equals 2.197 C (obtained from Tablecurve 2D, Version 5, 2000, AISN Software) and is the distance that carbon moves along the $x$-axis from the transition midpoint, and is symmetrical around the midpoint (Fig. 1). $C$ is a nonzero constant, and reflects the steepness of the transition width. The initial values for parameters were estimated from visual plots of the data to reduce the number of iterations when calculating the best-fitting sigmoidal curve.

The influence of the size $\left(\log _{10}\right)$ of the saltmarsh patch on the trend in $\delta^{13} \mathrm{C}$ values of each crab species among sampling positions was analysed using simple linear regression. Parameter estimates (derived from the non-linear model above) that describe the trend in the $\delta^{13} \mathrm{C}$ values of crabs were selected a priori for analysis, according to the predicted influence of patch size on the $\delta^{13} \mathrm{C}$ values of crabs at sampling positions across the saltmarsh-mangrove interface (Table 1).

\section{RESULTS}

The $\delta^{13} \mathrm{C}$ values of autotrophs could be separated into 3 bands: Sporobolus virginicus $(-15.4 \pm 0.1 \%$, MPB (-23.7 $\pm 0.3 \%$, Guest \& Connolly 2004) and Avicennia marina $\left(-28.1 \pm 0.1 \%\right.$ ). The $\delta^{13} \mathrm{C}$ values of MPB did not vary greatly between habitats $(-23.0 \pm 0.5 \%$ in saltmarsh, $-24.4 \pm 0.5 \%$ in mangroves).

For both crab species, and at all sites, the sigmoidal regression model provided a close fit of the relationship between $\delta^{13} \mathrm{C}$ values and the position of a crab in each habitat ( $\mathrm{p}<0.001$ for all; Figs. $3 \& 4$ ). The relationship between $\delta^{13} \mathrm{C}$ values and crab position was negative, with more enriched $\delta^{13} \mathrm{C}$ values in the saltmarsh habitat and increasingly depleted $\delta^{13} \mathrm{C}$ values with greater proximity to mangroves. The explanatory power of the sigmoidal regressions (measured as $\mathrm{r}^{2}$ ) in estimating $\delta^{13} \mathrm{C}$ from positions of invertebrates was high $\left(\mathrm{r}^{2}>0.80\right)$ for all sites except at Sites 2 and 4 for both species (0.64 for both sites for Parasesarma erythrodactyla; 0.67 and 0.50 for Australoplax tridentata at Sites 2 and 4, respectively; Figs. $3 \& 4$ ).

Most parameter estimates were not correlated with the size of the saltmarsh patch (Table 1), but their averages across the 10 sites indicated the extent of carbon movement and assimilation across the saltmarsh-mangrove interface. The average transition midpoint over all 10 patches was $0.2 \mathrm{~m}( \pm 0.9)$ into the mangroves for Parasesarma erythrodactyla and $2.0 \mathrm{~m}( \pm 0.9)$ into the mangroves for Australoplax tridentata (estimated from the $0 \mathrm{~m}$ position that demarcates the saltmarsh-mangrove interface). The extent of carbon movement and assimilation into each habitat measured from the transition midpoint, and referred to as the transition width, was $5.0 \mathrm{~m}( \pm 1.0)$ for $P$. erythrodactyla and $3.8 \mathrm{~m}( \pm 0.7)$ for $A$. tridentata.

The transition height was similar for both species (6.4 $\pm 0.5 \%$ for Parasesarma erythrodactyla, $5.6 \pm 0.7 \%$ for Australoplax tridentata). The upper and lower asymptotes (see Figs. 3 \& 4) represent invertebrate $\delta^{13} \mathrm{C}$ values at sampling positions within saltmarsh and mangrove habitats, excluding the 

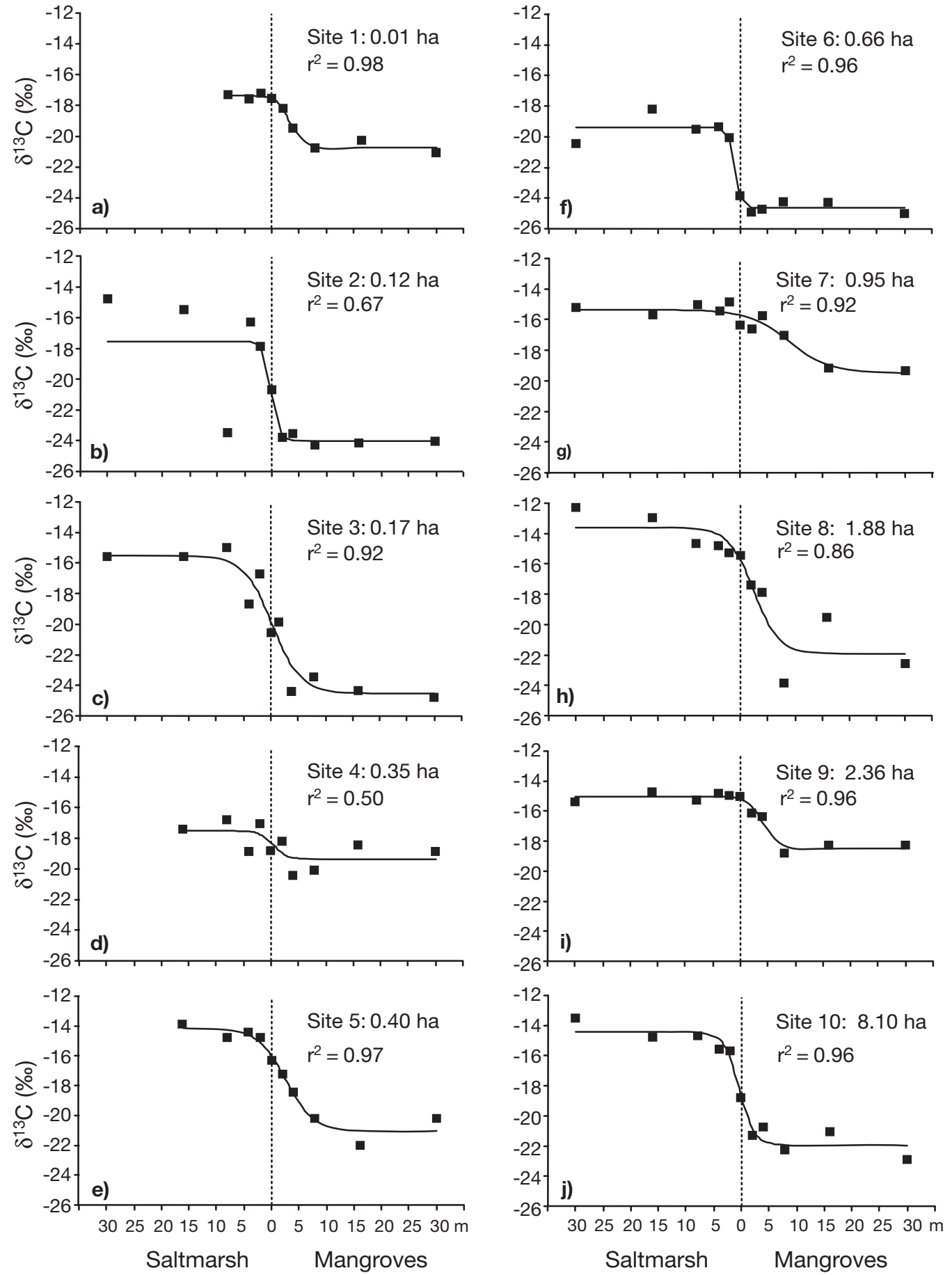

Fig. 4. Australoplax tridentata. Non-linear regression line of best fit for $\delta^{13} \mathrm{C}$ values and sampling positions for each site. Sites are numbered 1 to 10 in increasing order of saltmarsh patch size

saltmarsh-mangrove interface. In the saltmarsh, the invertebrate $\delta^{13} \mathrm{C}$ values closely matched the $\delta^{13} \mathrm{C}$ values of the saltmarsh grass. In the mangroves, invertebrate values were more enriched than the mangrove values, and were closer to, but still slightly more enriched than, the $\delta^{13} \mathrm{C}$ values of MPB.
From the regression analyses of parameter estimates and saltmarsh size, only the relationship between the upper asymptote (i.e. the $\delta^{13} \mathrm{C}$ values of crabs in saltmarsh habitat) and saltmarsh size was significant, and only for Parasesarma erythrodactyla (Table 1, Fig. 5a). The $\delta^{13} \mathrm{C}$ values of $P$. erythrodactyla in small saltmarsh 


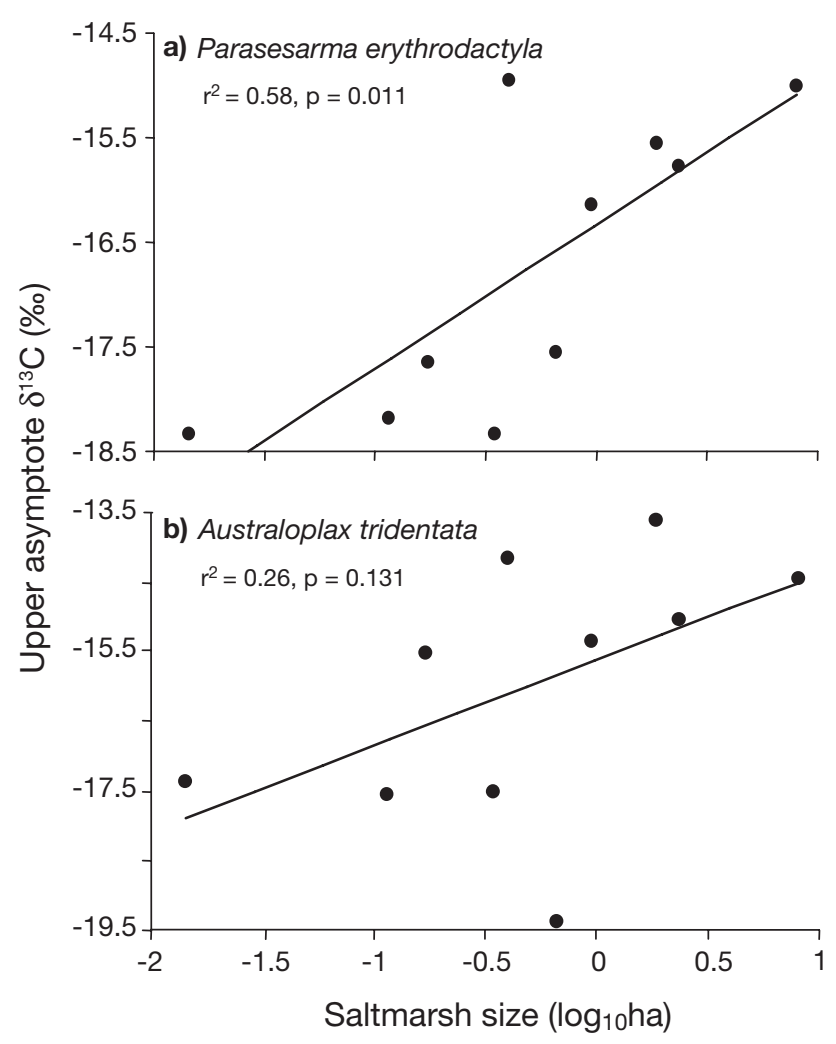

Fig. 5. (a) Parasesarma erythrodactyla, (b) Australoplax tridentata. Upper asymptote values $\left(\delta^{13} \mathrm{C}\right)$ for different-sized saltmarshes $\left(\log _{10}\right)(\mathrm{n}=10$ crabs $)$

patches were more negative (Site $1,-18.3 \pm 1.1 \%$; Fig. 5a) than those collected from larger patches (Site $10,-15.0 \pm 1.2 \%$; Fig. 5a). Whilst the upper asymptote of $\delta^{13} \mathrm{C}$ values of Australoplax tridentata were not significant (Site 1, $-17.4 \pm 0.3 \%$; Site 10,-14.4 $\pm 0.6 \%$; Fig. 5b), it followed the same trend with saltmarsh size as that of $P$. erythrodactyla.

\section{DISCUSSION}

\section{Influence of saltmarsh size on food web processes}

The relative trophic contribution of small patches (<0.3 ha) of saltmarsh was less than that of larger patches (0.4 to $8.1 \mathrm{ha})$ for the resident crab Parasesarma erythrodactyla. This was shown by the significantly more negative $\delta^{13} \mathrm{C}$ values of $P$. erythrodactyla collected $>5 \mathrm{~m}$ into the saltmarsh (and representing the upper asymptote in the model) in small patches $(<0.3 \mathrm{ha})$ than in large patches. The patterns of $\delta^{13} \mathrm{C}$ values of Australoplax tridentata were not significant, although they followed a similar trend. No other para- meters from the non-linear regression model of crab position across habitats and carbon isotope value varied significantly with saltmarsh size for both crab species.

Few other studies have examined the influence of habitat size on food web processes, but studies of terrestrial vertebrates (e.g. Stamps et al. 1987) suggest that the influence of habitat size is greater where the permeability (i.e. the ease of movement across habitats) of the habitat boundary is high (Marquet et al. 1993). In the present study, permeability refers to the ease with which carbon moves across the saltmarsh-mangrove interface and is assimilated by crabs. In large saltmarsh patches, the similarity of saltmarsh crab $\delta^{13} \mathrm{C}$ values to those of Sporobolus virginicus and the narrow transition width of $\delta^{13} \mathrm{C}$ values across the saltmarsh-mangrove interface indicate that permeability is low and limited to $5 \mathrm{~m}$ or less on either side of the saltmarsh-mangrove interface. Whilst the transition width in small saltmarsh patches was similar to that of large patches, the depleted $\delta^{13} \mathrm{C}$ values of crabs in the saltmarsh indicate that small saltmarsh patches are more susceptible or 'permeable' to the intrusion of allochthonous carbon sources, such as carbon from mangroves or phytoplankton.

\section{Scales of carbon movement and assimilation}

The movement of carbon and its assimilation by resident crab species in large saltmarsh patches adjacent to mangroves was restricted to a scale of several metres $(<5 \mathrm{~m})$. This result is consistent with the trend of other recent smaller-scale studies on the movement of carbon and its subsequent assimilation by invertebrates (Jennings et al. 1997). For example, in a study of the $\delta^{13} \mathrm{C}$ values of ocypodid crabs at sites separated by hundreds of metres, carbon sources varied enormously (Hsieh et al. 2002).

In a study of saltmarshes approximately 2 ha in area (Guest \& Connolly 2004), the $\delta^{13} \mathrm{C}$ values of crabs collected more than about $7 \mathrm{~m}$ from the saltmarsh-mangrove interface were close to those of Sporobolus virginicus. The $\delta^{13} \mathrm{C}$ values of crabs collected $>7 \mathrm{~m}$ into the mangroves were intermediate between mangroves and MPB. The similarity in the $\delta^{13} \mathrm{C}$ values of crabs with the dominant autotroph in the habitat in which they reside, and the separation of isotope ratios between the 2 habitats, indicate the extent of carbon movement and assimilation occurring within a transition zone about $7 \mathrm{~m}$ either side of the saltmarsh-mangrove boundary. These results, and those of large saltmarshes from the current study, provide strong evidence that the movement of carbon is occurring at a scale much smaller than has typically been examined 
in previous studies. For small saltmarshes, however, our results demonstrate depletion in the $\delta^{13} \mathrm{C}$ values of crabs right across the saltmarsh, indicating a larger contribution from allochthonous sources of carbon to crabs.

The transition midpoints of the sigmoidal curves also help to describe the movement and assimilation of carbon, and were close to the saltmarsh-mangrove interface for both crab species. This indicates that even for large saltmarshes, there was a small amount of energy transfer across the interface in both directions. However, there was a slightly greater movement and assimilation of saltmarsh carbon into the mangroves than from mangroves into the saltmarsh (i.e. the midpoint described by the model for Parasesarma erythrodactyla was $0.2 \pm 0.9 \mathrm{~m}$ and for Australoplax tridentata $2.1 \pm 0.9 \mathrm{~m}$ into the mangroves). The transition widths of large saltmarshes, however, suggest limited carbon movement $(<5 \mathrm{~m}$ either side of the transition midpoint for both species) and are at the smaller end of the scale that was measured.

\section{Crab diets}

The clear separation in the $\delta^{13} \mathrm{C}$ values of crabs located more than about $5 \mathrm{~m}$ into the saltmarsh and those located more than about $5 \mathrm{~m}$ into the mangroves (as indicated by the transition height) means that crabs residing in saltmarsh and mangroves derive their carbon from different sources. This is consistent with the results of previous studies on the diet of ocypodid and grapsid crabs that suggest a lack of dietary specialisation for some crab species (e.g. Sesarma leptosoma, Dahdouh-Guebas et al. 1999). For example, grapsid crabs have been reported to consume both saltmarsh plants (Iribarne et al. 1997) and mangrove leaf litter (Lee 1997). Ocypodid crabs have been described as feeding on bacteria (Dye \& Lasiak 1986), microalgae (Rodelli et al. 1984) and terrestrial grass (Hsieh et al. 2002).

In the current study, for crabs collected in large saltmarshes, their $\delta^{13} \mathrm{C}$ values closely matched that of the saltmarsh grass Sporobolus virginicus, indicating that this was their main source of dietary carbon. The $\delta^{13} \mathrm{C}$ values of crabs from small saltmarshes, however, were more depleted in ${ }^{13} \mathrm{C}$ than those from large saltmarshes. The more depleted $\delta^{13} \mathrm{C}$ values of crabs from smaller saltmarshes suggest that these crabs assimilate an alternate and more depleted carbon source, e.g. mangrove, MPB, or phytoplankton (ca. -20\%o, Fry 1984, Davenport \& Bax 2002).

The $\delta^{13} \mathrm{C}$ values of crabs collected at positions more than about $5 \mathrm{~m}$ into the mangroves were more enriched than the mangroves at all sites, regardless of the size of the adjacent saltmarsh. Thus, mangroves, saltmarsh grass and MPB may all contribute to the diet of mangrove crabs. Any contribution of saltmarsh grass to the diet of mangrove crabs suggests a larger-scale movement of carbon than the $5.0 \mathrm{~m}$ range indicated by saltmarsh crabs from large patches. However, a simpler explanation is that mangrove crabs rely predominantly on MPB and that the slight enrichment of crab values to MPB values (about $1 \%$ ) results from trophic fractionation (Peterson \& Fry 1987).

In small saltmarshes, the $\delta^{13} \mathrm{C}$ values of saltmarsh crabs were more depleted than that of the saltmarsh grass. The $\delta^{13} \mathrm{C}$ values of phytoplankton and the proximity of the sites surveyed to open water make phytoplankton a possible carbon source for saltmarsh crabs, and this may explain the disparity between the carbon isotope values of consumers and the dominant autotroph within each habitat. However, phytoplankton may only be an irregular source of carbon to saltmarsh crabs, as it can only be deposited on the marsh during flooding tides. At the sites surveyed, flooding tides typically occur on spring tides, but more frequently in periods of prolonged rainfall. Seagrass with its epiphytic algae is also present in southern Moreton Bay, seaward of mangroves, and has an enriched $\delta^{13} \mathrm{C}$ signature $(-12 \%)$ similar to that of saltmarsh grass (Melville \& Connolly 2003). Seagrass meadows produce more carbon than can be consumed in situ by animals (Duarte \& Cebrian 1996, Moncreiff \& Sullivan 2001), and seagrass deposited at the marsh sites may contribute small amounts of carbon to the diet of saltmarsh crabs. Terrestrial vegetation is an unlikely contributor of carbon to the $\delta^{13} \mathrm{C}$ values of crabs, as the sites surveyed were several kilometres from terrestrial vegetation.

The trend in the $\delta^{13} \mathrm{C}$ values of crabs across the saltmarsh-mangrove interface may also be explained by the movement and subsequent foraging by crabs across this transition zone (Guest et al. 2004a). However, Guest (2004) has shown that crabs rarely move more than about $1 \mathrm{~m}$ up or down the shore. Crab movement across the saltmarsh-mangrove interface is therefore not a plausible alternative to explain the trend in the $\delta^{13} \mathrm{C}$ values of crabs from saltmarsh patches of varying sizes. Small-scale movement of detrital carbon is the most likely explanation for the trend in the $\delta^{13} \mathrm{C}$ values of crabs (Connolly et al. 2005). It is possible that carbon moves among habitats more than is shown by the present results, but that it is not assimilated by crabs (stable isotope analysis of crabs tests only the movement and assimilation of carbon). Any movement of particulate carbon not utilised by invertebrates could be detected in future work by measuring carbon isotope values of detritus in superficial sediments. 


\section{CONCLUSIONS}

The results of this study, where significant, are consistent with our predicted influences of saltmarsh patch size. Very small saltmarshes contribute less carbon to food webs supporting resident crab species than do larger patches of saltmarsh. Unfortunately, such small saltmarsh patches are typically not incorporated into landscape-scale mapping. Patches of Sporobolus saltmarsh $<2$ ha in area comprise more than a third of saltmarshes in the study region (data provided by Dowling \& Stephens 1999), suggesting that small patches of saltmarsh may be relatively common throughout southern Moreton Bay. Our work shows that habitat patch size can influence pathways of carbon supply to invertebrates. The role of estuarine habitats in local food webs cannot be assumed to be independent of the size and configuration of habitats.

Acknowledgements. We thank the many volunteers for their assistance in the field, D. Gorman for laboratory assistance and $\mathrm{M}$. Arthur for assistance with statistical analyses. We are also grateful to S. Y. Lee for advice on crab movement and to $\mathrm{N}$. Loneragan for helpful comments on the manuscript. This work was funded by the CRC for Coastal Zone, Estuary and Waterway Management.

\section{LITERATURE CITED}

Arguiar MR, Sala OE (1999) Patch structure, dynamics and implications for the functioning of ecosystems. Trends Ecol Evol 14:273-277

Bell SS, Brooks RA, Robbins BD, Fonseca MS, Hall MO (2001) Faunal response to fragmentation in seagrass habitats: implications for seagrass conservation. Biol Conserv 100: 115-123

Bouillon S, Koedam N, Baeyens W, Satyanarayana B, Dehairs F (2004) Selectivity of subtidal benthic invertebrate communities for local microalgal production in an estuarine mangrove ecosystem during the post-monsoon period. J Sea Res 51:133-144

Brooks TM, Pimm SL, Oyugi JO (1999) Time lag between deforestation and bird extinction in tropical forest fragments. Conserv Biol 13:1140-1150

Cadenasso ML, Pickett STA, Weathers KC (2004) Effect of landscape boundaries on the flux of nutrients, detritus and organisms. In: Polis GA, Power ME, Huxel GR (eds) Food webs at the landscape level. The University of Chicago Press, Chicago, IL, p 154-168

Cantrell RS, Cosner C, Fagan WF (2001) How predator incursions affect critical patch size: the role of functional response. Am Nat 158:368-375

Connolly RM, Melville AJ, Hindell JS, Preston KM (2003) Stable isotope tracing of the contribution of seagrass production to subtropical fisheries species occurring outside seagrass areas. FRDC Final Report, Project 99/217, ISBN:0909291X

Connolly RM, Hindell JS, Gorman D (2005) Seagrass and epiphytic algae support the nutrition of a fisheries species, Sillago schomburgkii, in adjacent intertidal habitats. Mar Ecol Prog Ser 286:69-79

Dahdouh-Guebas F, Giuggioli M, Oluoch A, Vannini M, Can- nicci S (1999) Feeding habits of non-ocypodid crabs from two mangrove forests in Kenya. Bull Mar Sci 64:291-297

Davenport SR, Bax NJ (2002) A trophic study of a marine ecosystem off southeastern Australia using stable isotopes of carbon and nitrogen. Can J Fish Aquat Sci 59:514-530

Debinski DM, Holt RD (2000) A survey and overview of habitat fragmentation experiments. Conserv Biol 14:342-355

Donovan TM, Jones PW, Annand EM, Thompson III FR (1997) Variation in local-scale edge effects: mechanisms and landscape context. Ecology 78:2064-2075

Dowling R, Stephens K (1999) Coastal wetlands of southeastern Queensland: Maroochy Shire to New South Wales border. Queensland Herbarium, Environmental Protection Agency, Brisbane

Duarte CM, Cebrian J (1996) The fate of marine autotroph production. Limnol Oceanogr 41:1758-1766

Dye AH, Lasiak TA (1986) Microbenthos, meiobenthos and fiddler crabs: trophic interactions in a tropical mangrove sediment. Mar Ecol Prog Ser 32:259-264

Forman RTT, Godron M (1986) Landscape ecology. Wiley, New York

Fox BJ, Taylor JE, Fox MD, Williams C (1997) Vegetation changes across edges of rainforest remnants. Biol Conserv 82:1-13

France RL (1998) Estimating the assimilation of mangrove detritus by fiddler crabs in Laguna Joyuda, Puerto Rico, using dual stable isotopes. J Trop Ecol 14:413-425

Frost MT, Rowden AA, Attrill MJ (1999) Effect of habitat fragmentation on the macroinvertebrate infaunal communities associated with the seagrass Zostera marina L. Aquat Conserv Mar Freshw Ecosyst 9:255-263

Fry B (1984) ${ }^{13} \mathrm{C} /{ }^{12} \mathrm{C}$ ratios and the trophic importance of algae in Florida Syringodium filiforme seagrass meadows. Mar Biol 79:11-19

Gremillet D, Kuntz G, Delbart F, Mellet M and 6 others (2004) Linking foraging performance of a marine predator to local prey abundance. Funct Ecol 18:793-801

Guest MA (2004) Movement and assimilation of carbon by estuarine invertebrates. PhD dissertation, Griffith University, Gold Coast, QLD

Guest MA, Connolly RM (2004) Fine-scale movement and assimilation of carbon in saltmarsh and mangrove habitat by resident animals. Aquat Ecol 38:599-609

Guest MA, Connolly RM, Loneragan NR (2004a) Carbon movement and assimilation by invertebrates in estuarine habitat at a scale of metres. Mar Ecol Prog Ser 278:27-34

Guest MA, Connolly RM, Loneragan NR (2004b) Within- and among-site variability in $\delta^{13} \mathrm{C}$ and $\delta^{15} \mathrm{~N}$ for three estuarine producers: Sporobolus virginicus, Zostera capricorni, and epiphytes of Z. capricorni. Aquat Bot 79:87-94

Hemminga MA, van Soelen J, Maas YEM (1998) Biomass production in pioneer Spartina anglica patches: evidence for the importance of seston particle deposition. Estuar Coast Shelf Sci 47:797-805

Hsieh H, Chen C, Chen Y, Yang H (2002) Diversity of benthic organic matter flows through polychaetes and crabs in a mangrove estuary: $\delta^{13} \mathrm{C}$ and $\delta^{34} \mathrm{~S}$ signals. Mar Ecol Prog Ser 227:145-155

Iribarne O, Bortolus A, Botto F (1997) Between habitat differences in burrow characteristics and trophic modes in the southwestern Atlantic burrowing crab Chasmagnathis granulata. Mar Ecol Prog Ser 155:137-145

Jennings S, Renones O, Morales-Nin B, Polunin NVC, Moranta J, Coll J (1997) Spatial variation in the ${ }^{15} \mathrm{~N}$ and ${ }^{13} \mathrm{C}$ stable isotope composition of plants, invertebrates and fishes on Mediterranean reefs: implications for the study of trophic pathways. Mar Ecol Prog Ser 146:109-116 
Kneib RT (2000) Saltmarsh ecoscapes and production transfers by estuarine nekton in the southeastern US. In: Weinstein MP, Kreeger DA (eds) Concepts and controversies in tidal marsh ecology. Kluwer Academic Publishers, Dordrecht, p 267-292

Lee SY (1997) Potential trophic importance of the faecal material of the mangrove sesarmine crab Sesarma messa. Mar Ecol Prog Ser 159:275-284

Marquet PA, Fortin MJ, Pineda J, Wallin DO and 5 others (1993) Ecological and evolutionary consequences of patchiness: a marine-terrestrial perspective. In: Powell T, Levin S, Steele J (eds) Patch dynamics in marine and terrestrial environments. Springer-Verlag, Berlin, p 277-304

Melville AJ, Connolly RM (2003) Spatial analysis of stable isotope data to determine primary sources of nutrition for fish. Oecologia 136:499-507

Moncreiff CA, Sullivan MJ (2001) Trophic importance of epiphytic algae in subtropical seagrass beds: evidence from multiple stable isotope analyses. Mar Ecol Prog Ser 215:93-106

Editorial responsibility: Otto Kinne (Editor-in-Chief), Oldendorf/Luhe, Germany
Peterson BJ, Fry B (1987) Stable isotopes in ecosystem studies. Annu Rev Ecol Syst 18:293-320

Polis GA, Anderson WB, Holt RD (1997) Toward an integration of landscape and food web ecology: the dynamics of spatially subsidized food webs. Annu Rev Ecol Syst 28: 289-316

Robinson GR, Holt RD, Gaines MS, Hamburg SP, Johnson ML, Fitch HS, Martinko EA (1992) Diverse and contrasting effects of habitat fragmentation. Science 257: $524-526$

Rodelli MR, Gearing JN, Gearing PJ, Marshall N, Sasekumar A (1984) Stable isotope ratio as a tracer of mangrove carbon in Malaysian ecosystems. Oecologia 61:326-333

Stamps JA, Buechner M, Krishnan VV (1987) The effects of edge permeability and habitat geometry on emigration from patches of habitat. Am Nat 129:533-552

Stevens T, Connolly RM (2004) Testing the utility of abiotic surrogates for marine mapping at scales relevant to management. Biol Conserv 119:351-362

Submitted: March 30, 2005; Accepted: September 16, 2005 Proofs received from author(s): February 2, 2006 